\author{
ПРОБЛЕМИ \\ АГРОСТРАХУВАННЯ В \\ УКРАЇНІ ТА ШЛЯХИ \\ ÏХ ВИРІШЕННЯ
}

\author{
ВДОВЕНКО Л.О., \\ доктор економічних наук, професор, \\ завідувач кафедри фінансів, \\ банківської справи та страхування, \\ Вінницький національний \\ аграрний університет \\ (м. Вінниця)
}

\begin{abstract}
Статтю присвячено сучасним тенденціям ринку агрострахування в Україні. Установлено, щуо сільськогосподарське виробництво зі специфічними особливостями та в умовах кліматичних змін навколишнього середовища потребує належного страхового захисту від можливих збитків внаслідок несприятливих природних явищ та існуючих ризиків ведення аграрного бізнесу. Здійснено аналіз законодавчо-нормативного забезпечення страхових відносин. Визначено, щуо притаманні сільськогосподарському виробництву ризики $\epsilon$ системними $i$ спричиняють значні збитки для більшості сільськогосподарських товаровиробників одночасно, щу може призвести до великих страхових виплат, тому важливою складовою системи регулювання складними економічними процесами в сільському господарстві є страхування сільськогосподарської продукиії. Зроблено висновки, щуо одним із важливих стимулів ефрективного сільськогосподарського виробництва $\epsilon$ підтримка державою страхування пріоритетних видів сільськогосподарської продукиії.

Проаналізовано основні показники страхової діяльності, визначено їхні тенденції в розрізі регіонів Украӥни, виділено проблеми агрострахування в контексті учасників страхових відносин. Зроблено висновки щзодо необхідності активізації агрострахування як ключового засобу зростання потенціалу підприємств аграрного сектору економіки. Удосконалення системи агрострахування базується на врахуванні економічних інтересів учасників страхових відносин (страховиків, страхувальників та держави) та використанні крамого світового досвіду страхових відносин в аграрній сфері.

В основі удосконаленої системи агрострахування - иінова доступність, підвищення якості надання страхових послуг, формування ефективної інфраструктури страхового ринку, високий ступінь довіри до страховиків з боку страхувальників, диверсифікація спектру страхових продуктів за специфікою галузі, спроможність держави до реальної фінансової підтримки сільськогосподарського виробництва.
\end{abstract}

Ключові слова: страхування, страхова діяльність, агрострахування, страхові виплати, страхова премія, страхова сума, державно-приватне партнерство.

Табл.: 1. Рис.:1. Літ.: 10.

\title{
PROBLEMS OF AGRICULTURAL INSURANCE IN UKRAINE AND WAYS THEIR SOLUTIONS
}

\author{
VDOVENKO Larysa, \\ Doctor of Economics, Professor, Head of the Department of Finance, \\ banking and insurance, \\ Vinnytsia National Agrarian University \\ (Vinnytsya)
}


The article is dedicated to the current trends of the agricultural insurance market in Ukraine. It has been established that for silskogospodarske, in accordance with the specific features and skills of the middling community, the need for a proper insurance business from a variety of derivative businesses in the case of uncomfortable natural businesses of unfair natural businesses. It is established that the risks inherent in agricultural production are systemic and create significant fees for most agricultural producers at the same time, which can lead to large insurance payments, so there is a system of regulation of complex economic processes in agriculture is insurance of agricultural products. The analysis of the legislative and normative protection of insurance claims has been completed. The payments were made, which is one of the important incentives for effective government insurance.

The main indicators of insurance activity are analyzed, the development trends of the regions of Ukraine are determined, the problems of insurance and agricultural insurance are considered in the context of the participants in the events. A copy was made for the inexplicable activation of agricultural insurance as a key to the growth of the potential of the agricultural sector of the economy. In addition, the system of agricultural insurance is based on the protection of economic interests of the participants of the insurance companies (insurers, insurance and powers) and the short-term insurance of small losses in the aeronautical spheres.

Based on an improved agricultural insurance system, affordability, improving the quality of insurance services, forming an effective insurance market infrastructure, a high degree of trust in insurers by policyholders, diversification of insurance products by special industry, the state's ability to provide real financial support for agricultural production.

Key words: insurance, insurance business, agricultural insurance, insurance premiums, insurance premiums, insurance sum, state-private partnership.

Table.: 1. Fig.: 1. Lit.: 10.

\title{
ПРОБЛЕМЫ АГРОСТРАХОВАНИЯ В УКРАИНЕ И ПУТИ ИХ РЕШЕНИЯ
}

\author{
ВДОВЕНКО Л.А., \\ доктор экономических наук, профессор, заведующая кафедрой \\ финансов, банковского дела и страхования, \\ Винницикй национальный аграрный университет
} (2. Винница)

\begin{abstract}
Статья посвящена современным тенденциям на рынке агрострахования в Украине. Установлено, что сельскохозяйственное производство в соответствии со спеиифическими особенностями и в условиях климатических изменений окружающей среды, требует надлежсачего страховании бизнеса от различных убытков вследствии неприветливых погодных условий и существующих рисков ведения аграрного бизнеса. Произведен анализ законодательной и нормативной базы страховых отношений. Установлены, что присущие сельскохозяйственному производству риски являются системными и вызывают значительные убытки для большинства сельскохозяйственных товаропроизводителей одновременно, что может привести к большим страховым выплатам, поэтому важной составляющей системы регулирования сложными экономическими процессами в сельском хозяйстве является страхование сельскохозяйственной продукиии. Сделаны выводы, что одним из важных стимулов эффективного сельскохозяйственного производства есть поддержка государством страхования приоритетных видов сельхозпродукции.

Проанализированы основные показатели страховой деятельности, выявлены их тенденции среди развития Украины, выделены актуальные проблемы агрострахования в разрезе участников страхования. Сделань выводы о необходимости активизачии
\end{abstract}


агрострахования как ключевого фактора повышения потенииала предприятий аграрного сектора экономики. Улучшение системы агрострахования основано на поддерживании экономических интересов участников страховых отношений (страховые компании, аграрные предприятия и государство) и использования лучшей зарубежной практики страховых отномений в агропромышленном секторе.

В основе усовершенствованной системы агрострахования ценовая доступность, повышение качества предоставления страховых услуг, формирование эффективной инфраструктуры страхового рынка, высокая степень доверия к страховщикам со стороньы страхователей, диверсификачия спектра страховых продуктов за спецификой отрасли, способность государства к реальной финансовой поддержке сельскохозяйственного производства.

Ключевые слова: страхование, страховая деятельность, агрострахование, страховые платежи, страховая премия, страховая сумма, государственно-частное партнерство.

Табл.: 1. Рис.:1. Лит.: 10.

Постановка проблеми. Сільське господарство як важлива галузь економіки України сприяє забезпеченню продовольчої та економічної безпеки держави через виробництво сільськогосподарської продукції. Сільськогосподарське виробництво зі специфічними особливостями та в умовах кліматичних змін навколишнього середовища потребує належного страхового захисту від можливих збитків унаслідок несприятливих природних явищ та існуючих ризиків ведення аграрного бізнесу.

Недосконала система агрострахування в Україні не сприяє ефективному розвитку аграрного сектору економіки, тому чинний механізм страхового захисту сільськогосподарських товаровиробників потребує суттєвого вдосконалення з метою всеохоплюючого використання аграріями у вітчизняній практиці саме страхування у найбільш ризиковій сфері сільськогосподарському виробництві. Окрім інших, одним із важливих стимулів ефективного сільськогосподарського виробництва $\epsilon$ підтримка державою страхування пріоритетних видів сільськогосподарської продукції, що сприятиме поєднанню інтересів аграріїв, страховиків та держави як гаранта страхових відносин.

Аналіз останніх досліджень і публікацій. Страхова діяльність знайшла відображення у наукових працях вітчизняних та зарубіжних вчених: Алескерової Ю.В. [9], Базилевича В.Д., Борисової В.А., Василика О.Д., Грушка В.І., Лутака М.Д., Осадця С.С., Рейтмана Л.І., Стельмащука А.М. [6], Шахова В.В. та інших. Водночас донині залишаються не вирішеними проблеми агрострахування, що вимагає всебічного їх дослідження в умовах ринкових відносин та пошуку шляхів їх вирішення.

Мета дослідження - аналіз проблеми відносин аграріїв зі страховими компаніями та пошук шляхів удосконалення страхового захисту пріоритетної галузі економіки - сільського господарства.

Виклад основного матеріалу дослідження. У сучасних умовах трансформаційних змін в економіці України зростає роль та значення інституту страхування, яке є засобом страхового захисту інтересів зацікавлених сторін.

Страхові відносини та страхова діяльність опираються на відповідну законодавчу базу, яка зазнавала певних змін щодо аграрного сектору, але 
механізм страхового захисту сільськогосподарських товаровиробників досі залишається неефективним і потребує вдосконалення.

Основу системи правового регулювання страхової діяльності становить Закон України «Про страхування» [1], який визначив принципи державної демонополізації та державного нагляду за страховою діяльністю.

Відповідно до ст. 1 Закону України «Про страхування» [1], страхування вид цивільно-правових відносин щодо захисту майнових інтересів фізичних осіб та юридичних осіб у разі настання певних подій (страхових випадків), визначених договором страхування або чинним законодавством, за рахунок грошових фондів, що формуються шляхом сплати фізичними особами та юридичними особами страхових платежів (страхових внесків, страхових премій) та доходів від розміщення коштів цих фондів.

Під страховою діяльністю потрібно розуміти врегульовану нормами права господарську діяльність страховиків 3 надання страхових послуг за рахунок сформованих страхових фондів, що здійснюється на підставі ліцензії, як правило, 3 метою отримання прибутку.

Агрострахування за рахунок спеціально сформованих фондів достатньо ефективно регулює відтворювальний процес, забезпечуючи страховий захист сільськогосподарських товаровиробників, економічні інтереси страхових компаній та держави загалом. За допомогою агрострахування обмежуються $\mathrm{i}$ компенсуються матеріальні й нематеріальні збитки, пов'язані із виникненням непередбачуваних явищ та ризиків специфічної галузі - сільського господарства.

Подальша еволюція страхового законодавства зазнає постійних змін, що негативно позначається на розвитку агрострахування в Україні і свідчить про відсутність дієвого механізму страхового захисту товаровиробників - найбільш вразливих до ризиків сільськогосподарської діяльності.

Так, з метою стимулювання розвитку сільськогосподарського виробництва Законом України «Про державну підтримку сільського господарства України» від 24 червня 2004 року [2] визначено особливості державного регулювання ринку агрострахування шляхом запровадження комплексного та індексного страхування, а також створення Фонду аграрних страхових субсидій.

Згідно зі статтею 10 п.2 цього Закону комплексним вважалось страхування усіх з нижче перерахованих ризиків загибелі (втрати) сільськогосподарської продукції або її частини внаслідок:

а) заморозку, ожеледі, вимерзання;

б) граду або удару блискавки;

в) землетрусу;

г) лавини, земельного зсуву, земельного або земельно-водного селю;

г) пожежі, крім лісових пожеж;

д) бурі, урагану, бурану;

е) зливи, поводі, паводку;

є) посухи чи зневодження на землях, які підлягають примусовому орошенню або заводненню;

ж) епітофітотійного розвитку хвороб, розмноження шкідників рослин, 
притаманних Україні, а також хвороб, які стали наслідком настання будь-якого 3 ризиків, визначених у підпунктах "a" - "з" цього пункту;

3) протиправних дій осіб, що виражаються у крадіжках, хуліганських діях стосовно рослинних насаджень; зруйнуванні покриттів (несучих конструкцій) теплиць, парників, оранжерей.

При цьому об'єктом комплексного страхування є будь-який із таких об'єктів (іх комбінація): сума витрат, понесених у зв'язку з виробництвом окремого виду сільськогосподарської продукції; очікувана вартість сільськогосподарської продукції, що виробляється; очікуваний дохід (прибуток) від продажу сільськогосподарської продукції, що виробляється.

Стаття 10.3 цього Закону трактувала індексне страхування як страхування ризику втрати врожаю окремої сільськогосподарської культури у відношенні до усереднених натуральних показників ііі врожайності на визначеній території за попередні п'ять маркетингових періодів.

Було визначено, що правила індексного страхування, затверджені страховиком, підлягають реєстрації центральним органом виконавчої влади у сфері регулювання ринків фінансових послуг. Для цілей розрахунку розміру страхової виплати за індексним страхуванням використовується спотова ціна метричної одиниці застрахованої сільськогосподарської продукції, яка діє на організованому аграрному ринку на момент виникнення страхового випадку.

Стаття 11 Закону України «Про державну підтримку сільського господарства України» від 24 червня 2004 року №1877-ІУ була присвячена особливостям створення Фонду аграрних страхових субсидій (ФАСС) України як державної спеціалізованої установи для надання страхових субсидій виробникам сільськогосподарської продукції, що мала бути підзвітною та підконтрольною центральному органу виконавчої влади з питань формування та забезпечення державної аграрної політики [2].

Проте, вказані норми Закону виявилися неефективними, цей механізм не запрацював, тому 09 лютого 2012 року було прийнято окремий Закон України «Про особливості страхування сільськогосподарської продукції з державною підтримкою» №4391-VI, який набрав чинності з 01 липня 2012 року [3].

В зв'язку із змінами, внесеними на підставі Закону України від 09.02.2012 p. №4391-VI [3], розділ III (до якого входили вищезгадані статті 10, 11, в яких пропонувався механізм страхування через запровадження комплексного i індексного страхування та створення Фонду аграрних страхових субсидій) виключено із Закону України «Про державну підтримку сільського господарства України" від 24 червня 2004 року №1877-ІУ [2], а розділ II виключено на підставі Закону України № 985-IX від 05.11.2020 p.

Закон України «Про особливості страхування сільськогосподарської продукції з державною підтримкою» від 09.02.2012 p. №4391-VI [3] спрямований на регулювання відносин у сфері страхування сільськогосподарської продукції, що здійснюється із державною підтримкою, з метою захисту майнових інтересів сільськогосподарських товаровиробників і спрямований на забезпечення стабільності виробництва в сільському господарстві.

$$
\text { Згідно із нормами зазначеного Закону [3] страхування }
$$


сільськогосподарської продукції з державною підтримкою - це економічні відносини щодо страхового захисту майнових інтересів сільськогосподарських товаровиробників у разі настання певних подій (страхових випадків), визначених цим Законом, за рахунок грошових фондів, що формуються у страховика шляхом сплати страхувальником страхових платежів (премій), частина яких компенсується за рахунок державних субсидій та доходів від розміщення коштів цих фондів, яке здійснюється відповідно до положень цього Закону i визначається наявністю та особливостями ризиків, носіями яких $\epsilon$ сільськогосподарські рослини і тварини. Державна підтримка полягає у наданні сільськогосподарському товаровиробнику 3 державного бюджету грошових коштів у вигляді субсидій для оплати частини страхового платежу (страхової преміï), нарахованого за договором страхування. Однак, такий механізм не запрацював. Закон передбачав створення пула страхових компаній. Пул було створено, але ринкові компанії до нього не приєдналися.

Відповідно до Закону України «Про особливості страхування сільськогосподарської продукції з державною підтримкою» суб'єктами відносин страхування сільськогосподарської продукції 3 державною підтримкою $\epsilon$ страхувальники i страховики. Страхувальниками $\epsilon$ сільськогосподарські товаровиробники, які уклали зі страховиками договір страхування сільськогосподарської продукції 3 державною підтримкою. Сільськогосподарським товаровиробником визнається юридична особа незалежно від організаційно-правової форми, яка займається виробництвом сільськогосподарської продукції та/або розведенням, вирощуванням і виловом риби у внутрішніх водоймах та ії переробкою на власних чи орендованих потужностях, у тому числі з власновиробленої сировини на давальницьких умовах та здійснює операції з ії постачання [3].

Право страхувати сільськогосподарську продукцію мають сільськогосподарські товаровиробники, що провадять свою діяльність на території України і відповідають визначеним Кабінетом Міністрів України критеріям (крім нерезидентів). У разі передачі сільськогосподарських земель в оренду право страхувати сільськогосподарську продукцію, у тому числі посіви та урожай сільськогосподарських культур і багаторічних насаджень, належить орендареві, крім нерезидентів.

Умови страхування площ посівів озимих зернових сільськогосподарських культур $з$ державною підтримкою від сільськогосподарських ризиків на період перезимівлі висвітлені в Розпорядженні Національної комісії, що здійснює державне регулювання у сфері ринків фінансових послуг 30.10.2012 p. № 1968 р. [4]. При цьому предметом договору виступає майновий інтерес страхувальника, пов'язаний із володінням, користуванням та розпорядженням площею посіву озимих зернових сільськогосподарських культур, що належить страхувальнику на правах власності, оренди (суборенди). Договір страхування площ таких посівів укладається, окрім вільного волевиявлення сторін, на підставі: заяви страхувальника, форми Стандартного договору страхування, стандартних страхових тарифів для такого виду страхування, форм документів щодо 
укладення та супроводження договорів страхування сільськогосподарської продукції з державною підтримкою і врегулювання страхових випадків переліку застрахованих площ посівів озимих зернових сільськогосподарських культур. Обов'язковою умовою підтвердження інформації, наданої страхувальником у заяві на страхування площ посівів озимих зернових сільськогосподарських культур з державною підтримкою від сільськогосподарських ризиків на період перезимівлі, є підписання сторонами Договору акта огляду площ цих посівів. Вигодонабувачем за Договором є страхувальник або юридична особа, яка надає позику виробникам зерна 3 метою формування державного інтервенційного фонду шляхом проведення державних форвардних закупівель зерна або призначена страхувальником особа, яка може зазнати збитків внаслідок настання страхового випадку.

Так, станом на 12.02.2019 р. ліцензію на провадження страхової діяльності у формі добровільного страхування сільськогосподарської продукції мають 64 страхові компанії, серед яких ПрАТ “Страхова компанія “АХА страхування", ПрАТ «Українська Акціонерна Страхова компанія «АСКА», ПрАТ «Страхова компанія «БРОКБІЗНЕС», ТДВ «Страхова компанія «ГАРДІАН», ПАТ «Страхова Компанія «МЕГА-ГАРАНТ», ПрАТ «Акціонерна Страхова компанія «ІНГО Україна», ПрАТ «Страхова компанія «Країна», ПАТ «Страхова компанія «Оранта-Січ», ПрАТ «Страхова компанія «ПЗУ Україна», ПрАТ «Страхова група «ТАС», ПрАТ «Українська аграрно-Страхова компанія», ПрАТ «Страхова компанія «Універсальна», ПрАТ «Українська пожежно-страхова компанія» та ПрАТ «Страхова компанія «Гарант-система» та інші [5].

Притаманні сільськогосподарському виробництву ризики $\epsilon$ висококорельованими (системними) і можуть викликати значні збитки для великої кількості сільгоспвиробників одночасно, що може призвести до великих страхових виплат. Саме тому важливою складовою системи регулювання складними економічними процесами в сільському господарстві є страхування сільськогосподарської продукції, яке забезпечує управління ризиками в аграрному секторі та сприяє створенню підгрунтя для стійкого економічного зростання сільськогосподарського виробництва [6, с.13].

Так, загалом у 2018 андерайтинговому році страхові компанії уклали 1207 договорів страхування сільськогосподарських культур та багаторічних насаджень (661 - на зимовий та 546 - на весняно-літній період), що на 185 одиниць менше, ніж у 2014 році (1392 од.) (табл.1).

Упродовж 2014-2018 рр. спостерігається тенденція то зменшення (з 1392 одиниць у 2014 р. до 793 одиниць у 2016 р. або в 1,8 раза), то збільшення (з 793 одиниць в 2016 р. до 1207 одиниць в 2018 р. або в 1,6 раза) кількості укладених договорів страхування сільськогосподарських культур, що продиктовано фінансовими можливостями та умовами здійснення аграрного бізнесу.

За аналізований період середня застрахована площа сільськогосподарських культур в Україні становить 770,8 тис. га.

У 2018 р. застрахована площа сільськогосподарських культур становила 974 тис. га і збільшилась порівняно з 2014 р. на 242 тис. га або на 33\%, а порівняно з попереднім 2017 р. - зросла на 313 тис. га або на 47,4\%. 
Упродовж 2014-2018 рр. страхова сума (у межах якої страховик відповідно до умов договору страхування зобов'язаний здійснити виплату страхового відшкодування при настанні страхового випадку) зросла з 3055 млн грн. у 2014 р. до 6675 млн грн. у 2018 р. або у 2,2 раза.

Таблиия 1

Динаміка показників страхування сільськогосподарських культур в Україні

\begin{tabular}{|l|c|c|c|c|c|c|}
\hline Показники & 2014 p. & 2015 p. & 2016 p. & 2017 p. & 2018 p. & $\begin{array}{c}\text { Відхилення } \\
2018 \text { р. до } \\
2014 \text { p. } \\
(+;-)\end{array}$ \\
\hline Кількість договорів, од. & 1392 & 1062 & 793 & 957 & 1207 & -185 \\
\hline Площа, тис. га & 732 & 689 & 700 & 661 & 974 & 242 \\
\hline Страхова сума, млн грн. & 3055 & 3969 & 6240 & 5933 & 6675 & 3620 \\
\hline Сума премії, млн грн. & 72,8 & 77,7 & 157,0 & 204,3 & 206,6 & 133,8 \\
\hline Рівень виплат, \% & 7,6 & 12,9 & 44,2 & 4,9 & 4,2 & $-3,4$ \\
\hline Середня ставка премії, \% & 2,4 & 2,0 & 2,5 & 3,4 & 3,1 & 0,7 \\
\hline
\end{tabular}

Джерело: складено автором за [5]

Загальна страхова сума за договорами страхування сільськогосподарських культур та багаторічних насаджень у 2018 р. на 12,5\% більша, ніж минулого 2017 р. (5933 млрд грн.).

Сума страхових премій, яку сплачують одноразово аграрії за ризик страхової компанії, зросла за 2014-2018 pр. у 2,8 раза (3 72,8 млн грн. до 206,6 млн грн.), що свідчить про зростання вартості страхових послуг для аграріїв.

Середня ставка страхової премії за весь андерайтинговий 2018 рік склала $3,1 \%$, зокрема 3,6\% - за зимовий період та 3,0\% - за період весна-літо.

Упродовж 2014-2016 рр. спостерігаємо зростання рівня виплат за страхуванням сільськогосподарських культур загалом - 3 7,6\% до 44,2\%, в подальшому частка виплат різко скоротилась і у 2018 р. вона становила лише $4,2 \%$, і цей факт негативно впливає на майбутні страхові відносини між страхувальниками-аграріями і страховиками (рис.1).

Аналізуючи страхування сільськогосподарських культур в розрізі областей України, варто відзначити, що впродовж 2014-2018 pp., окрім 2016 р., незмінними лідерами за кількістю укладених договорів $€$ Вінницька та Дніпропетровська області.

У 2018 p. найбільшу кількість договорів страхування сільськогосподарських культур було укладено у Дніпропетровській (125) та Кіровоградській (108), Чернігівській (83) та Вінницькій (82) областях. Найменшу кількість договорів було укладено у Чернівецькій (5), Рівненській (7) та Волинській (17) областях.

Першість серед областей за показником застрахованої площі у 2018 р. належить Хмельницькій області (115,8 тис. га або 11,9\%). За нею Дніпропетровська (92,5 тис. га або 9,5\%), Харківська (83,2 тис. га або 8,5\%), 
Чернігівська $(80,4$ тис. га або 8,3\%), Полтавська $(78,6$ тис. га або $8,1 \%)$ та Сумська $(67,4$ тис. га або 6,9\%).

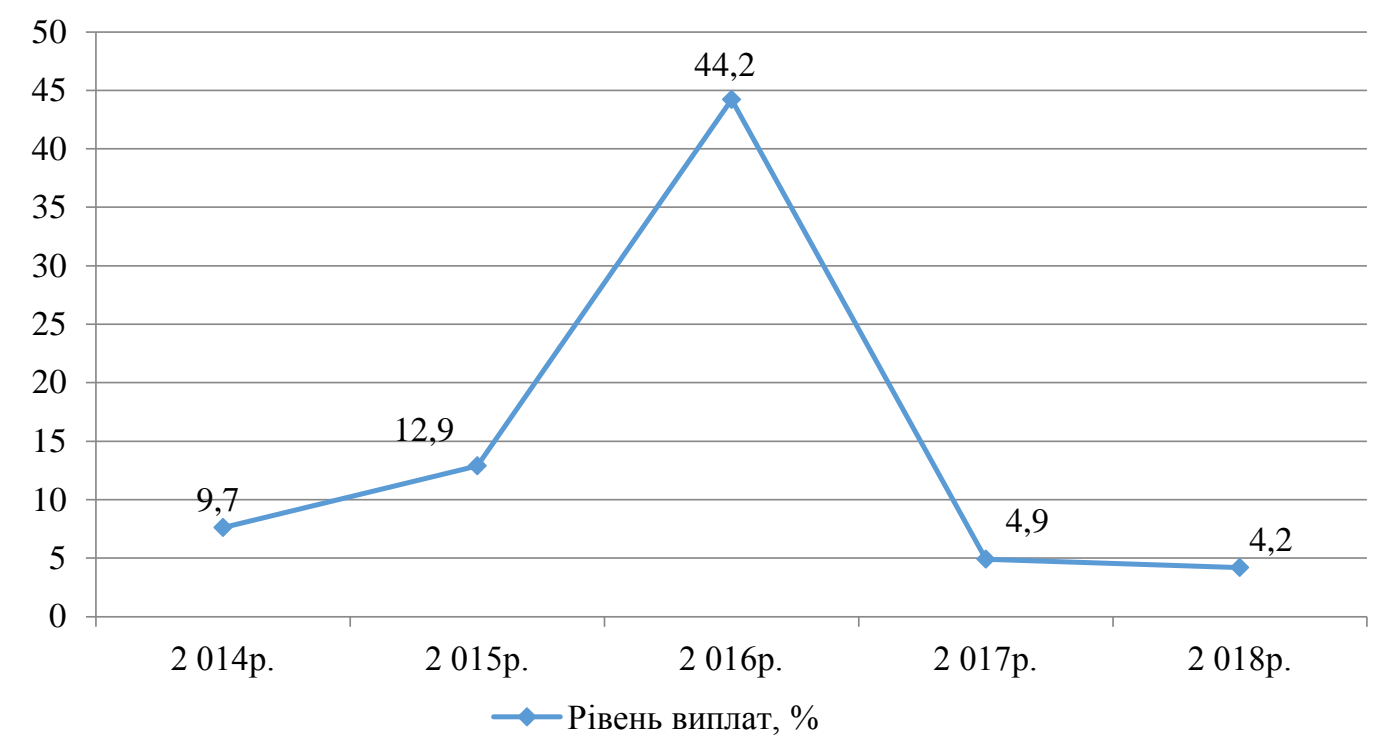

\section{Рис. 1. Зміна частки виплат за агрострахуванням в Україні y 2014-2018 pp.}

Джерело: побудовано автором на основі [5]

За обсягом зібраних страхових премій у 2018 р. області України розташувалися таким чином: Херсонська (23,8 млн грн. або $11,4 \%)$, Дніпропетровська (22,6 млн грн. або 10,8\%), Полтавська (19,3 млн грн. або 9,2\%), Сумська (17,6 млн грн. або 8,4\%), Миколаївська (15,6 млн грн. або 7,5\%), Хмельницька (13,1 млн грн. або 6,3\%), Тернопільська (11,3 млн грн. або 5,4\%), Вінницька (11,1 млн грн. або 5,3\%) та Чернігівська (10,4 млн грн. або 5,0\%).

Щорічно скорочується частка виплат страхувальникам: якщо першість за виплатами у 2017-му андерайтинговому році утримувала Хмельницька область - 40,3\% (3,1 млн грн.), то у 2018-му андерайтинговому році першість за виплатами належить Вінницькій області - 28,1\% (2,4 млн грн.).

За кількістю укладених договорів страхування сільськогосподарських культур у 2018 р. першість належить страховим компаніям "ПЗУ” (345 договорів або 28,6\% від загальної кількості, «Інго Україна» (236 договорів або 19,6\%), «АХА» (179 договорів або 14,8\%), «АСКА» (158 договорів або 19,6\%), «Універсальна» (126 договорів або 10,4\%), «Брокбізнес» (62 договори або 5,1\%), «Країна» (52 договори або 4,3\%). Практично ці самі компанії укладали договори аграрного страхування і в попередніх роках.

Страхові виплати за договорами агрострахування здійснили у 2018 р. 6 страхових компаній («ПЗУ» - 41,2\% від усього обсягу виплат; “АХА” - 22\%; «АСКА»-18,8\%; «Країна» - 10,2\%; «Інго Україна» - 5,8\%; «Універсальна» 2,0 \% відповідно).

Найбільший обсяг виплат упродовж 2015-2018 pp. за видами сільськогосподарських культур був здійснений за договорами страхування озимої пшениці. Так, у 2018 р. на страхування озимої пшениці було укладено 614 
договорів або 50,9\%, озимого ріпака (307 договорів або 24,4\%), кукурудзи (114 договорів або 9,4\%), соняшника (77 договорів або 6,4\%), озимого ячменю (40 договорів або $3,3 \%)$, озимого жита (13договорів або 1,1\%), ярої пшениці (8 договорів або $0,7 \%$ ).

3 погляду сільськогосподарських товаровиробників потрібно розглядати наявні проблеми агрострахування: недостатність фінансових ресурсів для сплати страхових внесків, низький ступінь довіри до страховиків, низький рівень фінансової грамотності аграріїв та 3 боку страхових компаній зростання вартості страхових премій, відсутність страхування типових за специфікою галузі ризиків, недостатня гарантія одержання страхового відшкодування страхувальниками. Крім того, агрострахування $\epsilon$ більш ризиковим і затратним видом страхування порівняно з іншими видами.

Низький рівень ризиків сільськогосподарських товаровиробників пов'язаний із підвищеною ризиковістю страхування врожаю і необхідністю в разі настання страхового випадку виплати значних страхових відшкодувань, що негативно впливатиме на фінансовий стан страховиків.

Гальмівними факторами розвитку підприємств аграрного сектору економіки є недосконала законодавча база та відсутність реальної державної підтримки розвитку галузі через дієві механізми страхового захисту.

Стельмащук А.М. [6, с. 16] виділяе такі проблеми в системі державної підтримки аграрного страхування:

- недостатність обсягів субсидування, непрозорість і недостатню гнучкість процесів субсидування;

- недостатні знання про можливості агрострахування, на етапі укладення договору помилково оцінюється рівень страхового покриття;

- для більшості господарств ціна страхового полісу є великою, а державні субсидії господарства отримують пізніше сплати страхової премії, адже не всі сільгоспвиробники можуть дозволити собі страхування свого майна, високий рівень кредиторської заборгованості, яку мають підприємства

- в даному виді страхування діють жорсткі терміни сплати страхових внесків, що збігаються 3 періодами підготовки і проведення сезонних сільськогосподарських робіт.

- складність процедури отримання субсидій та укладення договорів страхування;

- сільгоспвиробники отримують необхідні їм кошти з великим запізненням або не в повному обсязі;

- відсутність необхідних і ефективних засобів захисту інтересів і прав агровиробників у відносинах зі страховиками».

Для поліпшення умов агрострахування та залучення сільгоспвиробників в дану сферу можна використовувати такі методи:

- зниження діючих в законодавстві мінімумів втрати врожаю, що дасть можливість аграріям страхувати посіви при будь-якому рівні загибелі;

- розширення переліку ризиків для сільськогосподарських культур такими природними явищами, як тривалі зливи, рання поява сніжного покриву $\mathrm{i}$ 
промерзання верхнього шару грунту;

- введення гнучких програм агрострахування та можливості державної підтримки для регіонів з високоризикових землеробством;

- виведення агрострахування зі складу «єдиної субсидії» [6].

Світовий досвід (країн Свропи) засвідчує, що у багатьох країнах існує ефективна система страхування в аграрному секторі, що регулюється законодавчо, а аграрії покривають свої ризики та мінімізують фінансові втрати. У більшості країн аграрії отримують державну підтримку в разі застрахованості посівів сільськогосподарських культур.

Лідером в агрострахуванні є США, де 90\% господарств є застрахованими, там держава змушує страхові компанії страхувати усіх сільськогосподарських товаровиробників за наявності відповідного стандартного продукту, а пізніше розподіляються ризики між страховою компанією і державою.

Тобто, за державно-приватного партнерства (США, Німеччина, Франція, Іспанія, Португалія, Ізраїль, Туреччина, Австрія, Китай) держава визначає систему ризиків, які будуть компенсуватися за рахунок субсидій, визначає, яка частина витрат виробників на страхування врожаю чи тварин буде компенсована за рахунок субсидій та здійснює організацію перестрахування, а приватні компанії здійснюють компенсацію втрат за програмами страхування, які не відшкодовуються державою. Роль страховика полягає в адмініструванні, організації та просуванні страхових послуг. У разі настання катастрофічних збитків, держава пропонує страховикам програми перестрахування або застосовує механізми міжнародного перестрахування. Розвиток державноприватного партнерства можна стимулювати через дольові субсидії, податкові пільги, через платформи співпраці та національні управління зі збуту.

Проте, на відміну від України, в якій діяльність у сфері сільського господарства страхують лише 2-3\% представників аграрного сектору, у європейських країнах частка застрахованої сільськогосподарської діяльності коливається в межах 50-70\% [8].

Страхові компанії в Україні сьогодні не отримують підтримки з боку держави щодо послуг в аграрній сфері, а гіркий досвід сьогодення, коли через посуху загинули 300 тис. га, свідчить про необхідність запровадження ефективної системи агрострахування для зменшення збитків від ризиків специфічних галузей сільського господарства.

Фундаментальні перетворення в системі сільськогосподарського страхування, зумовлені якісно новими економічними умовами, обмежили обов'язковий характер методів страхового захисту, які постійно використовувались як державні важелі впливу на сільське господарство [9, с.34].

Нині впроваджуються ініціативи щодо зміни законодавства, впровадження системи агрострахування за зразком США, коли існує розмежування між державою та приватним страховим сектором, що, на нашу думку, врахує кращий світовий досвід і сприятиме розвитку агрострахування в Україні 3 дієвими механізмами страхового захисту сільськогосподарських товаровиробників.

Результатом таких законодавчих ініціатив $є$ прийнятий Закон України «Про внесення змін до деяких законів України щодо функціонування 
Державного аграрного реєстру та удосконалення державної підтримки виробників сільськогосподарської продукції» від 05.11.2020 p. №985-IX [10], в якому ініціюється «пріоритетність надання державної підтримки малим фермерським господарствам, у тому числі сімейним фермерським господарствам, які мають у власності або користуванні не більше 100 га земель сільськогосподарського призначення та річний дохід яких від реалізації продукції не перевищуе 5 мільйонів гривень», при цьому вказано, що «справедливість державної підтримки сільського господарства України забезпечується шляхом пропорційності розподілу державної підтримки та обмеження максимального розміру підтримки на одного виробника сільськогосподарської продукції», також передбачено відшкодування втрат аграріям внаслідок ризиків в сільському господарстві. Зокрема, в пункті $17^{-2} .8$ цього Закону йдеться про те, що «сільськогосподарським товаровиробникам можуть відшкодовуватися втрати від пошкодження посівів сільськогосподарських культур внаслідок надзвичайних ситуацій техногенного та природного характеру. Відшкодування здійснюється шляхом виплати бюджетної дотації на одиницю пошкоджених угідь. Для отримання сільськогосподарськими товаровиробниками та сільськогосподарськими кооперативами, які постраждали від надзвичайних ситуацій природного характеру, кредитів можуть надаватися державні гарантії у порядку, передбаченому Бюджетним кодексом України та згідно із Законом «Про Державний бюджет України на відповідний рік».

Однак, на нашу думку, виконання затверджених законодавчих ініціатив, зокрема, відшкодування втрат від пошкодження посівів сільськогосподарських культур, напряму залежатиме від можливостей дохідної частини Державного бюджету України та сприятливої фінансової політики держави, спрямованої на розвиток та реальну підтримку аграрного сектору економіки, на кшталт, світового досвіду.

Зокрема, в статті $2^{-1} .5$ прийнятого Закону [10] стверджується підхід, що «ефективність державної підтримки сільського господарства України забезпечується шляхом створення сприятливих умов для здійснення сільськогосподарської діяльності, підвищення якості та конкурентоспроможності сільськогосподарської продукції з метою мінімізації природно-кліматичних та економічних ризиків сільськогосподарського виробництва та гарантування продовольчої безпеки держави.

Висновки. Агрострахування у специфічних умовах ведення аграрного бізнесу повинно бути ключовим засобом зростання потенціалу підприємств аграрного сектору економіки, а перспективи його розвитку значною мірою залежатимуть від професійного рівня тих страховиків, які працюватимуть 3 притаманними сільському господарству ризиками, зокрема, від їхньої здатності адекватно оцінити та ефективно управляти ними.

В основі вдосконаленої системи агрострахування, яка базується на врахуванні економічних інтересів учасників страхових відносин (страховиків, страхувальників та держави): цінова доступність, підвищення якості надання 
страхових послуг, формування ефективної інфраструктури страхового ринку, високий ступінь довіри до страховиків з боку страхувальників, диверсифікація спектру страхових продуктів за специфікою галузі, спроможність держави до реальної державної підтримки сільськогосподарського виробництва.

\section{Список використаних джерел}

1. Про страхування: Закон України від 07.03.1996 року № 85/96-ВР: URL: http://zakon.rada.gov.ua/cgi-bin/laws/main.cgi?nreg=85\%2F96-\%E2\%F0 (дата звернення: 14.09.2020).

2. $\quad$ Про державну підтримку сільського господарства України: Закон України від 24.06.2004 року № URL: https://zakon.rada.gov.ua/laws/show/1877-15\#Text. (дата звернення: 14.09.2020).

3. Про особливості страхування сільськогосподарської продукції 3 державною підтримкою: Закон України від 09.02.2012 p. № 4391-VI. URL:: https://zakon.rada.gov.ua/laws/show/4391-17\#Text (дата звернення: 14.09.2020).

4. Про деякі питання здійснення страхування сільськогосподарської продукції з державною підтримкою: Розпорядження Національної комісії, що здійснює державне регулювання у сфері ринків фінансових послуг 30.10.2012 p. №1968. URL: https://zakon.rada.gov.ua/laws/show/z1970-12\#Text (дата звернення: 14.09.2020).

5. Ринок агрострахування України у 2018-му андерайтинговому році. Аналітичне дослідження. URL: https://agro.me.gov.ua/storage/ app/sites/1/\%D1\%83\%D0\%BF\%D1\%80\%D0\%B0\%D0\%B2\%D0\%BB\%D1\%96\%D 0\%BD\%D0\%BD\%D1\%8F\%20\%D1\%84\%D1\%96\%D0\%BD\%D0\%B0\%D0\%BD\% D1\%81\%D1\%96\%D0\%B2/\%D0\%A1\%D1\%82\%D1\%80\%D0\%B0\%D1\%85\%D1\% 83\%D0\%B2\%D0\%B0\%D0\%BD\%D0\%BD\%D1\%8F/\%20\%D0\%B0\%D0\%B3\%D1 \%80\%D0\%BE\%D1\%81\%D1\%82\%D1\%80\%D0\%B0\%D1\%85\%D1\%83\%D0\%B2\% D0\%B0\%D0\%BD\%D0\%BD\%D1\%8F\%20\%20\%D1\%83\%202018.pdf (дата звернення: 14.09.2020).

6. Стельмащук А.М. Формування ринкової моделі агрострахування на засадах державно-приватного партнерства. Інноваційна економіка. 2019. №1-2. C. $13-24$.

7. Агрострахування та держпітримка: чи складеться дует? URL: $\quad$ https://agravery.com/uk/posts/show/agrostrahuvanna-ta-derzpitrimka-ciskladetsa-duet (дата звернення: 02.10.2020).

8. Михайлов А.М. Фінансові інструменти формування інвестиційних ресурсів в аграрному секторі національної економіки в умовах глобалізаційних викликів. Економіка АПК. 2019. №3. С. 52-60.

9. Aleskerova Y., Kovalenko L, Havryliuk V. Innovative financial criteria for methodological approaches to the assessment of agrarian insurance. Baltic Journal of Economic Studies. 2019. Vol. 5, No. 4. P. 34-41. Web of Science. DOI: https://doi.org/10.30525/2256-0742/2019-5-4-34-41. 
10. Про внесення змін до деяких законів України щодо функціонування Державного аграрного реєстру та удосконалення державної підтримки виробників сільськогосподарської продукції: Закон України від 05.11.2020 р. №985-IX. URL: https://zakon.rada.gov.ua/laws/show/985-20\#n84

\section{Referens}

1. Pro strachuvania: Zakon Ukrainy vid 07.03.1996 r. № 85/96-BP: URL:: http://zakon.rada.gov.ua/cgi-bin/laws/main.cgi?nreg=85\%2F96-\%E2\%F0.

2. Pro derhavnu pidtrymky silskoho gospodarstva Ukrainy: Zakon Ukrainy vid 24.06.2004 r. № 1877-IV URL:: https://zakon.rada.gov.ua/laws/show/1877$15 \#$ Text.

3. Pro osoblyvosti strakhuvania silskohospodarskoi produkcii z dezhavnoyu pidtrymkoyu: Zakon Ukrainy vid 09.02.2012 p. №4391-VI [Elertronyi resurs]. Rezhym dostupu: https://zakon.rada.gov.ua/laws/show/4391-17\#Text.

4. Pro deyaki pytania zdiysnenia strakhuvania silskohospodarskoi produkcii z dezhavnoyu pidtrymkoyu: Rozporyadzhenia Nacionalnoi komisii shcho zdiysniuye derzhavne reguluvania u sferi rynkiv finansovyh poslug 30.10.2012 p. №1968. URL:: https://zakon.rada.gov.ua/laws/show/z1970-12\#Text.

5. Rynok agrostrakhuvania Ukrainy u 2018 anderajtynhovomu roci. Analitychne doslidzhenia. URL: https://agro.me.gov.ua/storage/app/sites/1/\%D 1\%83\%D0\%BF\%D1\%80\%D0\%B0\%D0\%B2\%D0\%BB\%D1\%96\%D0\%BD\%D0\%B D\%D1\%8F\%20\%D1\%84\%D1\%96\%D0\%BD\%D0\%B0\%D0\%BD\%D1\%81\%D1\%9 $6 \% \mathrm{D} 0 \% \mathrm{~B} 2 / \% \mathrm{D} 0 \% \mathrm{~A} 1 \% \mathrm{D} 1 \% 82 \% \mathrm{D} 1 \% 80 \% \mathrm{D} 0 \% \mathrm{~B} 0 \% \mathrm{D} 1 \% 85 \% \mathrm{D} 1 \% 83 \% \mathrm{D} 0 \% \mathrm{~B} 2 \% \mathrm{D}$ 0\%B0\%D0\%BD\%D0\%BD\%D1\%8F/\%20\%D0\%B0\%D0\%B3\%D1\%80\%D0\%BE\% D1\%81\%D1\%82\%D1\%80\%D0\%B0\%D1\%85\%D1\%83\%D0\%B2\%D0\%B0\%D0\%B D\%D0\%BD\%D1\%8F\%20\%20\%D1\%83\%202018.pdf.

6. Stelmashchuk, A.M. (2019) Formuvania rynkovoi modeli agrostrakhuvania na zasadah derzhavno-pryvatnoho partnerstva [Formation of a market model of agricultural insurance at the ambush of state-private partnership]. Inovaciyna economika. - Innovation economy. 1-2,13-24. [in Ukrainian].

7. Agrostrakhuvania ta derzhpidtrymka chy skladetsia duet? [Elertronyi resurs]. Rezhym dostupu: https://agravery.com/uk/posts/show/agrostrahuvanna-taderzpitrimka-ci-skladetsa-duet.

8. Myhaylov, A.M. (2019) Finansovyi instrument formuvania investyciinyh resursiv $\mathrm{v}$ agrarnomu sektori nacionalnoi economiky $\mathrm{v}$ umovah globalizaciynukh vuklykiv [Financial instruments for the formation of investment resources in the agrarian sector of the national economy in the minds of global wiklikiv]. Economika APK - Economics of the agro-industrial complex.3, 52-60. [in Ukrainian].

9. Aleskerova, Y., Kovalenko, L, Havryliuk, V. (2019). Innovative financial criteria for methodological approaches to the assessment of agrarian insurance. Baltic Journal of Economic Studies. Vol. 5, No. 4. S. 34-41. (Web of Science). DOI: https://doi.org/10.30525/2256-0742/2019-5-4-34-41.

10. Pro vnesenia zmin do deyakych zakoniv Ukrainy schodo funkcionuvania Dezhavnoho agrarnogo reyestru ta udoskonalenia dezhavnoyi pidtrymky vyrobnykiv 
silskogospodarskoi produkcii Zakon Ukrainy vid 05.11.2020 r. 985-IX. URL: https://zakon.rada.gov.ua/laws/show/985-20\#n84.

\section{Відомості про автора}

ВДОВЕНКО Лариса Олександрівна, доктор економічних наук, професор, завідувач кафедри фінансів, банківської справи та страхування, Вінницький національний аграрний університет, вул. Сонячна, 3, м. Вінниця, 21008, e-mail: vdovenko_larisa@i.ua

VDOVENKO Larysa, Doctor of Economics, Professor, Head of the Department of Finance, banking and insurance, Vinnytsia National Agrarian University, 21008, Vinnytsia, Soniachna str, 3, e-mail: vdovenko_larisa@i.ua

ВДОВЕНКО Лариса Александровна, доктор экономических наук, профессор, заведующая кафедрой финансов, банковского дела и страхования, Винницкий национальный аграрный университет, ул. Солнечная, 3, г. Винница, 21008, e-mail: vdovenko_larisa@i.ua

УДК 330.341.1

DOI: $10.37128 / 2411-4413-2020-4-3$

ІННОВАЦІЙНИЙ РОЗВИТОК ПІДПРИЕМСТВ ХАРЧОВОї ПРОМИСЛОВОСТІ УКРАЇНИ
КОВАЛЕНКО О.В., доктор економічних наук, стариий науковий співробітник, завідувач відділу економічних досліджень, Інститут продовольчих ресурсів НААН України (м. Kü̈в)

ГАРБАР Ж.В., доктор економічних наук, доцент, професор кафедри аграрного менеджменту та маркетингу, Вінницький національний аграрний університет (м. Вінниця)

У статті узагальнено та систематизовано особливості інноваційної діяльності підприємств харчової промисловості в Україні. Проаналізовано динаміку обсягу та 